\title{
Incontinence associated dermatitis in elderly people admitted to a university hospital
}

\author{
Dermatite associada à incontinência em idosos internados em um hospital universitário \\ Dermatitis relacionada a la incontinencia en ancianos internados en un hospital universitário
}

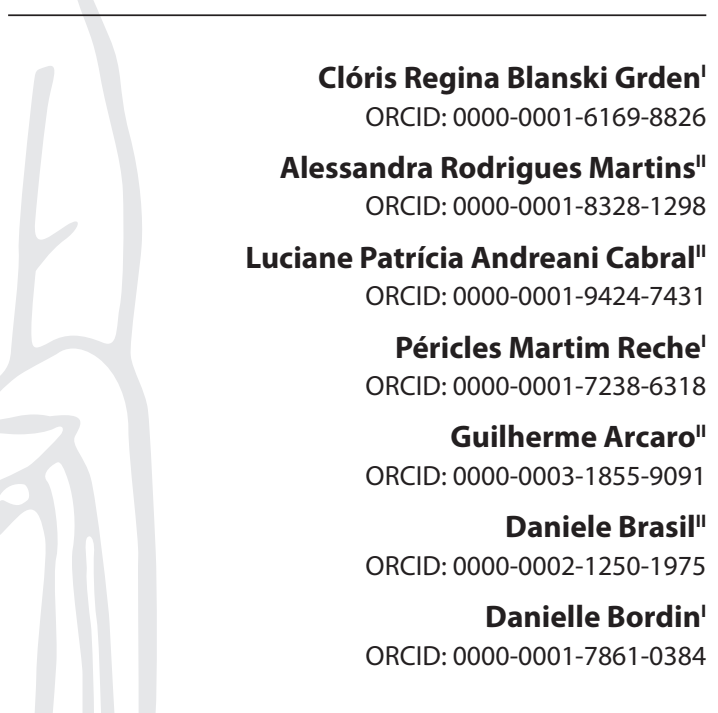

'Universidade Estadual de Ponta Grossa. Ponta Grossa, Paraná, Brazil.

"Universidade Estadual de Ponta Grossa, Hospital Universitário Regional dos Campos Gerais. Ponta Grossa, Paraná, Brazil.

How to cite this article: Grden CRB, Martins AR, Cabral LPA, Reche PM, Arcaro G, Brasil D, et al. Incontinence associated dermatitis in elderly people admitted to a university hospital.

Rev Bras Enferm. 2020;73(Suppl 3):e20190374. doi: http://dx.doi.org/10.1590/0034-7167-2019-0374

Corresponding author: Clóris Regina Blanski Grden E-mail: reginablanski@hotmail.com

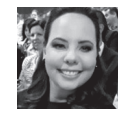

EDITOR IN CHIEF: Antonio José de Almeida Filho ASSOCIATE EDITOR: Priscilla Broca

Submission: 08-13-2019 Approval: 06-17-2020

\begin{abstract}
Objective: To identify the frequency and factors associated to incontinence associated dermatitis in elderly people. Methods: Cross-sectional study with 202 elderly patients admitted to a university hospital between September 2017 and January 2018. Data collection included: cognitive screening, sociodemographic and clinical questionnaire. It was performed exploratory and descriptive analysis, where prevalence and ratios (PR) were calculated. Results: Prevalence of injury was 9.4\%, age range 70-79 years (13.5\%), African American (21.4\%), hospitalization period $\geq 21$ days (44.4\%), in use of nasogastric tube (33.3\%), medical device $(11.3 \%)$, restricted mobility $(18.5 \%)$. It was associated with hospitalization period, use of nasogastric tube, restricted mobility, medical devices, and cognition. Conclusion: It was confirmed an average frequency of incontinence associated dermatitis in elderly patients and association to factors such as hospitalization period, immobility, cognition, use of nasogastric tube and devices. It must be highlighted the importance of prevention measures, early detection, assessment and monitoring of this type of injury.

Descriptors: Geriatric Nursing; Dermatitis; Elderly; Skin Ageing; University Hospitals.
\end{abstract}

\section{RESUMO}

Objetivo: Identificar a prevalência e os fatores associados à dermatite associada à incontinência em idosos. Métodos: Estudo transversal, com 202 idosos internados em um hospital universitário, entre setembro de 2017 a janeiro de 2018. A coleta de dados contemplou: rastreio cognitivo, questionário sociodemográfico e clínico. Realizou-se análise exploratória e descritiva, sendo calculadas as prevalências e razões de prevalência (RP). Resultados: Prevalência da lesão foi de 9,4\%, faixa etária $70-79$ anos (13,5\%), raça negra (21,4\%), tempo de internação de $\geq 21$ dias $(44,4 \%)$, em uso de sonda nasoenteral (33,3\%), dispositivo médico (11,3\%), mobilidade restrita $(18,5 \%)$. Apresentou-se associada com o tempo de internação, sonda nasoenteral, mobilidade restrita, dispositivos médicos e cognição. Conclusão: Verificou-se a média prevalência de dermatite associada à incontinência em idosos internados e associação aos fatores: tempo de internação, imobilidade, cognição, uso de sonda nasoenteral e dispositivos. Destaca-se a importância de ações de prevenção, identificação precoce, avaliação e monitoramento desse tipo de lesão. Descritores: Enfermagem Geriátrica; Dermatite; Idoso; Envelhecimento da Pele; Hospitais Universitários.

\section{RESUMEN}

Objetivo: Identificar la prevalencia y los factores relacionados a la dermatitis relacionada a la incontinencia en ancianos. Métodos: Estudio transversal, con 202 ancianos internados en un hospital universitario, entre septiembre de 2017 a enero de 2018. La recogida de datos contempló: rastreo cognitivo, cuestionario sociodemográfico y clínico. Se realizó análisis exploratorio y descriptivo, siendo calculadas las prevalencias y razones de prevalencia (RP). Resultados: Prevalencia de la lesión ha sido de 9,4\%, franja etaria 70-79 años (13,5\%), raza negra $(21,4 \%)$, tiempo de internación de $\geq 21$ días $(44,4 \%)$, en uso de sonda nasoenteral $(33,3 \%)$, dispositivo médico $(11,3 \%)$, movilidad restricta $(18,5 \%)$. Se presentó relacionada con el tiempo de internación, sonda nasoenteral, movilidad restricta, dispositivos médicos y cognición. Conclusión: Se verificó la media prevalencia de dermatitis relacionada a la incontinencia en ancianos internados y relación a los factores: tiempo de internación, inmovilidad, cognición, uso de sonda nasoenteral y dispositivos. Se destaca la importancia de acciones de prevención, identificación precoz, evaluación y monitoreo de ese tipo de lesión. Descriptores: Enfermería Geriátrica; Dermatitis; Anciano; Envejecimiento de la Piel; Hospitales Universitarios. 


\section{INTRODUCTION}

The aging process causes changes in different physiological systems, contributing to the reduction of functional capacity and making the individual more susceptible to chronic diseases, with increased chances of hospitalization ${ }^{(1-3)}$, a process in which the elderly person becomes vulnerable to skin lesions ${ }^{(4)}$.

Among the occurring physiological changes in the elderly, those related to the urinary and fecal systems contribute to incontinence, which may interfere with mobility and provoke skin maceration, contributing to the appearance of lesions ${ }^{(5-7)}$, particularly those associated with incontinence or moisture.

Several terms have been used to describe skin lesions associated with incontinence: perineal dermatitis, irritating diaper dermatitis, moisture maceration, contact dermatitis, among others ${ }^{(4)}$. However, for the present study it has been used the term incontinenceassociated dermatitis (IAD), defined as an inflammation characterized by erythema, epidermis erosion and macerated appearance of the skin from contact with urine or feces ${ }^{(8)}$. Such definition was standardized in the $1^{\text {st }}$ Consensus in the Journal of Wound Ostomy \& Continence Nurses (JWOCN) ${ }^{(9)}$.

Authors emphasize that skin tissue tolerance and health condition $^{(1,10)}$, cognitive and nutritional conditions ${ }^{(6)}$, mechanical friction $^{(6,11)}$, use of diapers ${ }^{(10,12)}$ and inadequate genital hygiene ${ }^{(12)}$, use of medications ${ }^{(11)}$ are contributing factors for lesions associated with incontinence or moisture.

A descriptive and correlational survey conducted with 5,342 elderly patients admitted to an intensive care unit in 36 regions of the United States identified an overall IAD frequency rate of $21.3 \%{ }^{(13)}$. This represents a significant number of patients with such condition. Thus, for this study, the following research question was adopted: What is the prevalence and factors related to incontinence associated dermatitis (IAD) in elderly patients admitted to a university hospital?

Despite being considered an unpleasant event that causes discomfort and pain ${ }^{(1,7,11)}$, contributing significantly to the increase of hospitalization time and cost, especially in elderly patients ${ }^{(10,14-15)}$, IAD is preventable. Therefore, it is essential that the nursing staff identifies and monitors risk factors, as well as establishes prevention and treatment protocols. In comparison to other types of lesions, in practice, there is a shortage of epidemiological studies on the subject, mainly in the national context ${ }^{(14)}$.

\section{OBJECTIVE}

To identify the frequency and factors related to incontinence associated dermatitis (IAD) in elderly people admitted to a university hospital.

\section{METHODS}

\section{Ethical Aspects}

The project was approved by the Research Ethics Committee with human beings of a higher education institution. The ethical precepts of voluntary and consented participation of each participant were respected, according to the resolution current at the time the research was conducted.

\section{Design, period, and place of study}

A transversal observational study, guided by the STROBE tool, performed with elderly patients in the medical, neurology and infectiology clinics of a teaching hospital in Campos Gerais, in a city located in the State of Paraná, from September 2017 to January 2018. The institution is characterized as public and educational, with 172 beds, with an average hospitalization of 914 patients/month in the year 2018.

\section{Population or sample; inclusion and exclusion criteria}

The sample size calculation was determined by means of Epi. Info ${ }^{\circledast} 7.1 .4$ software, considering for the total number the monthly admissions of the last year (581 elderly), with 5\% accuracy, 95\% confidence interval and design effect 1, for a frequency of $22 \%$ of elderly with incontinence associated dermatitis (IAD), following the frequency of an international study developed by Beeckman and collaborators ${ }^{(16)}$. The total calculated resulted in a sample of 182 individuals. An additional 10\% was added to the sample, considering possible losses, resulting in a final sample of 202 individuals.

The parameters used to select the sample were: a) to be over or equal to 60 years old; $b$ ) to be hospitalized for at least 24 hours in the institution, during the period of data collection; c) to have cognitive ability to answer the questions of the study, evaluated through the Mini Mental State Examination ${ }^{(17)}$.

In case of elderly people without cognitive conditions to answer the survey questions in the interview stage, the caregiver/family was invited to participate, for which the following inclusion criteria were listed: a) to be a caregiver/family, 18 years old or more; b) to live with the elderly person for at least three months, being the latter the respondent when the elderly person has cognitive deficit.

\section{Study protocol}

In the initial phase of data collection, cognitive screening was performed through the Mini Mental State Exam (MMSE). The instrument has 11 items grouped into seven categories, represented by groups of specific cognitive functions: temporal orientation, spatial orientation, immediate memory, attention and calculation, evocation memory, language and visual constructive capacity ${ }^{(18)}$. Scores range from 0 to 30 , with the following cut-off points for evaluation: 13 points for illiterate individuals; 18 points for lower and medium education; and 26 points for higher education ${ }^{(17)}$.

In order to classify and characterize the sample, a sociodemographic and clinical questionnaire was prepared specifically for the study. The sample was characterized based on the investigation of the following socio-demographic and health variables: gender, age, family income, education, skin color, profession, diagnosis, laboratory and imaging tests, medications, nutrition, medical devices, mobility, reason and time of hospitalization.

Afterwards the patient went through a physical examination, which included tegumentary evaluation and identification of incontinence associated dermatitis, classified according to Beeckman 
and collaborators ${ }^{(19)}$, who classified the IAD in two categories, namely: category 1 , when the skin is intact with the presence of erythema and/or edema; category 2, presence of moderate or severe erosion of the epidermis, where may be signs of infection.

\section{Analysis of results and statistics}

The data were analyzed by Stata ${ }^{\circledast}$ software, version 12 (StataCorp LP, College Station, TX, USA), submitted to exploratory and descriptive analysis. Subsequently, confirmatory analysis was performed by calculating prevalence and ratios (PR). To investigate the associations between independent and dependent variables, Fisher's exact test and chi-square test were applied, with statistical significance of $p<0.05$.

\section{RESULTS}

From the 202 elderly evaluated, there was a predominance of males $(105 ; 51.9 \%), 60-69$ years of age $(88 ; 43.6 \%)$, lower education ( 1 to 4 years unfinished) $(128 ; 63.4 \%)$, white people (156; $77.2 \%)$, medium period of hospitalization of 6.5 days (SD $=0.5$ ) and restricted mobility $(81 ; 40.1 \%)$. Regarding clinical aspects, most of the elderly used some medical device (158; 78.2\%), as well as a significant portion used a nasogastric tube ( $n=30 ; 14.8 \%$ ) and obtained between 0 and 13 points in the MMSE $(56 ; 27.7 \%)$.

The occurrence of incontinence associated dermatitis (IAD) was $9.41 \%(n=19)$ in the elderly patients, especially in females $(11 ; 11.3 \%)$, 70 years of age or older $(14 ; 23.5 \%)$, illiterate $(4 ; 16 \%)$,
African American (3); 21.4\%), with hospitalization time equal or superior to 21 days $(4 ; 44.4 \%)$, feeding by nasoenteral tube $(10 ; 33.3 \%)$, in use of medical device $(18 ; 11.3 \%)$, bedridden (15; $18.5 \%)$ and MMSE score between 0 and 13 points (12; 21.4\%).

It was also found that the IAD was significantly associated with longer period of hospitalization ( $p=0.002)$, use of a nasogastric tube $(p=0.001)$, medical devices $(p=0.050)$, restricted mobility $(p=0.001)$ and cognition $(p=0.004)$.

\section{DISCUSSION}

In this study, the condition of incontinence associated dermatitis (IAD) was in conformity with the global prevalence, which presents a wide variation, between $5.6 \%$ and $50 \%{ }^{(8)}$, and was congruent with what had been evidenced by a study performed with 376 patients (average age of 62 years) from an Australian hospital, in which IAD was present in $10 \%$ of the elderly patients ${ }^{(20)}$. However, the current results showed a higher incidence when compared to the multicenter survey developed with 51,045 patients admitted to hospitals in the United States and Canada (average age was 65 years), which detected the condition in $4.1 \%$ of the elderly patients ${ }^{(15)}$.

The variability in the incidence of IAD can be attributed to the absence of an internationally approved method, as well as the difficulty in identifying it. Another obstacle is the shortage of epidemiological studies regarding IAD in the hospital setting ${ }^{(14,15)}$ considering that most of those studies involving the subject are developed in Long Term Institutions for the Elderly (LTIE) ${ }^{(15)}$.

Table 1 - Distribution of prevalence and associated factors in elderly patients admitted in a university hospital, City of Ponta Grossa, State of Paraná, Brazil, 2017-2018

\begin{tabular}{|c|c|c|c|c|c|c|}
\hline Variables & & Total (\%) & Present IAD & Do not present IAD & $\mathbf{R P}$ & $p$ value \\
\hline IAD & & & $19(9.41)$ & $183(90.59)$ & & \\
\hline Gender & $\begin{array}{l}\text { Male } \\
\text { Female }\end{array}$ & $\begin{array}{l}105(51.98) \\
97(48.02)\end{array}$ & $\begin{array}{c}8(7.62) \\
11(11.34)\end{array}$ & $\begin{array}{l}97(92.38) \\
86(88.66)\end{array}$ & $\begin{array}{l}1.00 \\
1.48\end{array}$ & 0.365 \\
\hline Age range & $\begin{array}{c}60-69 \text { years } \\
70-79 \text { years } \\
>80 \text { years }\end{array}$ & $\begin{array}{l}88(43.56) \\
74(36.63) \\
40(19.81)\end{array}$ & $\begin{array}{c}5(5.68) \\
10(13.51) \\
4(10)\end{array}$ & $\begin{array}{c}83(94.32) \\
64(86.49) \\
36(90)\end{array}$ & $\begin{array}{l}1.00 \\
2.37 \\
1.76\end{array}$ & $\begin{array}{l}0.086 \\
0.294\end{array}$ \\
\hline Education* & $\begin{array}{l}\text { High } \\
\text { Illiterate } \\
\text { Lower } \\
\text { Average }\end{array}$ & $\begin{array}{c}22(10.90) \\
25(12.38) \\
128(63.36) \\
27(13.36)\end{array}$ & $\begin{array}{c}2(9.09) \\
4(16) \\
10(7.81) \\
3(11.11)\end{array}$ & $\begin{array}{c}20(90.91) \\
21(84) \\
118(92.19) \\
24(88.89)\end{array}$ & $\begin{array}{l}1.00 \\
1.76 \\
0.85 \\
1.22\end{array}$ & $\begin{array}{l}0.397 \\
0.551 \\
0.599\end{array}$ \\
\hline Skin Color & $\begin{array}{c}\text { Brown } \\
\text { African American } \\
\text { White }\end{array}$ & $\begin{array}{l}32(15.84) \\
14(6.93) \\
156(77.23)\end{array}$ & $\begin{array}{l}1(3.13) \\
3(21.43) \\
15(9.62)\end{array}$ & $\begin{array}{c}31(96.88) \\
11(78.57) \\
141(90.38)\end{array}$ & $\begin{array}{l}1.00 \\
0.21 \\
3.07\end{array}$ & $\begin{array}{l}0.077 \\
0.203\end{array}$ \\
\hline Hospitalization period & $\begin{array}{l}1-10 \text { days } \\
11-20 \text { days } \\
21 \text { days or more }\end{array}$ & $\begin{array}{c}168(83.17) \\
25(12.38) \\
9(4.45)\end{array}$ & $\begin{array}{c}10(5.95) \\
5(20) \\
4(44.44)\end{array}$ & $\begin{array}{l}158(94.05) \\
20(80) \\
5(55.56)\end{array}$ & $\begin{array}{l}1.00 \\
3.36 \\
7.46\end{array}$ & $\begin{array}{l}0.014 \\
0.002\end{array}$ \\
\hline Nutrition & $\begin{array}{c}\text { Oral } \\
\text { Enteral }\end{array}$ & $\begin{array}{l}172(85.15) \\
30(14.85)\end{array}$ & $\begin{array}{c}9(5.23) \\
10(33.33)\end{array}$ & $\begin{array}{l}163(94.77) \\
20(66.67)\end{array}$ & $\begin{array}{l}1.00 \\
6.37\end{array}$ & 0.001 \\
\hline Use of medical devices & $\begin{array}{l}\text { No } \\
\text { Yes }\end{array}$ & $\begin{array}{l}44(21.78) \\
158(78.22)\end{array}$ & $\begin{array}{c}1(2.27) \\
18(11.39)\end{array}$ & $\begin{array}{c}43(97.73) \\
140(88.61)\end{array}$ & $\begin{array}{l}1.00 \\
5.01\end{array}$ & 0.050 \\
\hline Mobility & $\begin{array}{l}\text { Independent } \\
\text { Supported } \\
\text { Restricted } \\
\text { Use of technology** }\end{array}$ & $\begin{array}{l}77(38.12) \\
32(15.84) \\
81(40.10) \\
12(5.94)\end{array}$ & $\begin{aligned} 2 & (2.60) \\
1 & (3.13) \\
15 & (18.52) \\
1 & (8.33)\end{aligned}$ & $\begin{array}{l}75(97.40) \\
31(96.88) \\
66(81.48) \\
11(91.67)\end{array}$ & $\begin{array}{l}1.00 \\
1.20 \\
7.12 \\
3.20\end{array}$ & $\begin{array}{l}0.651 \\
0.001 \\
0.355\end{array}$ \\
\hline MMSE & $\begin{array}{c}26-30 \text { points } \\
19-25 \text { points } \\
14-18 \text { points } \\
0-13 \text { points }\end{array}$ & $\begin{array}{l}42(20.79) \\
82(40.59) \\
22(10.90) \\
56(27.72)\end{array}$ & $\begin{array}{c}1(2.38) \\
5(6.10) \\
1(4.55) \\
12(21.43)\end{array}$ & $\begin{array}{l}41(97.62) \\
77(93.90) \\
21(95.45) \\
44(78.57)\end{array}$ & $\begin{array}{c}1.00 \\
2.56 \\
1.90 \\
9\end{array}$ & $\begin{array}{l}0.335 \\
0.572 \\
0.004\end{array}$ \\
\hline
\end{tabular}


Similar to other studies ${ }^{(13,21)}$, sociodemographic aspects such as skin color, gender and education were not associated to IAD. And although the variable "age" does not present statistical significance to this condition, some authors point out such factor as important for the occurrence of this type of lesion, highlighting that the risk increases proportionally with age, i.e., the increase in the year of life corresponds to a 3\% increase in the risk of IAD (13-14).

It is understood that the aging process favors the appearance of comorbidities and contributes to the event of hospitalization, as well as to increase the time and cost of this condition ${ }^{(13,22)}$. On this variable, a significant association was found in the two major cut-off points: 11-20 days and 21 days or more. This results from the exacerbation of the contributing aspects for IAD ${ }^{(13)}$, so that the longer the period of hospitalization, the greater the exposure of the elderly to factors such as diaper use, humidity, immobility and infectious agents, which predispose to the development of skin lesions, such as IAD ${ }^{(21)}$, thus conferring an increase in hospital expenses ${ }^{(24)}$.

Nutrition is an important determinant in the prognosis of patients at high risk for developing skin lesions, as well as a fundamental part of their healing process ${ }^{(6,24)}$. The present study evidenced the association between enteral diet and IAD, corroborating a research-correction of a historical hospital cohort ${ }^{(21)}$, which aimed to estimate survival and verify factors associated with IAD in critically ill patients at a public hospital: it was evidenced that the risk of bacterial contamination, high osmolarity and lack of fiber related to enteral tube feeding ${ }^{(10,25)}$ favor the establishment of diarrhea, which is considered an important factor for the formation of IAD ${ }^{(26)}$.

Due to physiological changes in the aging process, the elderly may present low weight, loss of mass and muscle strength ${ }^{(27)}$, the latter being considered as one of the responsible for the mobility deficit ${ }^{(14)}$. Nevertheless, mobility is cited in national and international studies ${ }^{(13,19)}$ as a predictor of risk for skin lesions. The present study, diverging from that cited by the authors, found that restricted mobility was significantly associated with $I A D$, ratifying what is observed during practical experience, as patients with restricted mobility commonly presented difficulties in performing basic activities of daily living.
In this age segment, in addition to the above-mentioned modifications, it should be highlighted that cognitive complaints are frequent; and, during the hospitalization process, it is common for the elderly to present a variation in the level of consciousness ${ }^{(28)}$, which may cause loss of functional capacity and autonomy. For this study, cognitive screening was performed through the MMSE, in which a significant association with IAD was identified. However, no other investigations were found that pointed out the relationship between MMSE and IAD. Authors ${ }^{(14)}$ point out that the use of sedatives and muscle beta-blockers affect the cognitive state, generating in individuals a greater propensity to develop IAD when compared to patients with preserved cognition.

\section{Limitations of the study}

The sample size is a limitation because, although it is representative of a population in a given place, the results shown here do not represent other population groups or other territories.

\section{Contributions to Nursing, Health or Public Policy}

The results pointed out in this study contribute with the national epidemiological data on the subject, as well as to the direction of planning of actions for prevention and monitoring of lesions due to dermatitis associated to incontinence, considering the factors associated to this condition.

\section{CONCLUSION}

The present study identified the average frequency of incontinence associated dermatitis in elderly patients in a university hospital, confirming other surveys about this condition, whose prevalence variability is wide. Important factors associated to this condition that are commonly present during hospitalization are: use of nasogastric tube, use of medical devices, restricted mobility, longer hospitalization period and cognition. The results presented demonstrate the relevance of prevention actions to avoid IAD, as well as its evaluation and monitoring.

\section{REFERENCES}

1. Nascimento DC, Cunha CV, Pena LHG, Souza NVDO, Marques GS. Dermatite associada à incontinência na população idosa: uma revisão integrativa. Rev Hosp Univ Pedro Ernesto. 2016;15(1):37-42. doi: 10.12957/rhupe.2016.22840

2. Pinheiro FM, Santo FHE, Chibante CLP, Pestana LC. Profile of hospitalized elderly according to Virginia Henderson: contributions for nursing care. Rev Pesqui: Cuid Fundam. 2016;8(3):4789-92. doi: 10.9789/2175-5361.2016.v8i3.4789-4795

3. Nunes BP, Soares MU, Wachs LS, Volz PM, Saes MO, Duro SMS, et al. Hospitalization in older adults: association with multimorbidity, primary health care and private health plan. Rev Saúde Pública. 2017;(51)43:01-09. doi: 10.1590/s1518-8787.2017051006646

4. Souza NR, Freire DA, Souza MAO, Santos ICRV, Santos LV, Bushatsky M. Fatores predisponentes para o desenvolvimento da lesão por pressão em pacientes idosos: uma revisão integrativa. Rev Estima. 2017;15(4):229-39. doi: 10.5327/Z1806-3144201700040007

5. Holloway S. Skin considerations for older adults with wounds. Brith J Commun Nurs. 2019;24(6):S15-S19. doi:10.12968/bjcn.2019.24.sup6.s15

6. Beeckman D. A decade of research on Incontinence-Associated Dermatitis (IAD): evidence, knowledge gaps and next steps. J Tissue Viab. 2017;26(1):47-56. doi: 10.1016/j.jtv.2016.02.004

7. Tavares AP, Ramos AF, Mendes F, Lopes M, Parreira P, Fonseca CJV. Prevention and Treatment of Incontinence-Associated Dermatitis (IAD): contributes of nursing intervention. J Perioperative Crit Intens Care Nurs. 2017;3(1):1-2. doi: 10.4172/2471-9870.1000e114

8. Beeckman D, Van Damme N, Schoonhven L, Van Lancker A, Kottner J, Beele H, et al. Interventions for preventing and treating incontinenceassociated dermatitis in adults. Cochrane Database System Rev. 2016;11(CD011627):1-74. doi: 10.1002/14651858.CD011627.pub2 
9. Gray M, Bliss DZ, Doughty DB, Ermer-Seltun J, Kennedy-Evans KL, Palmer MH. Incontinence-associated Dermatitis. J Wound Ostomy Continence Nurs. 2007;34(1):45-54. doi:10.1097/00152192-200701000-00008

10. Strehlow BR, Fortes VLF, Amarante MV. Incontinence-Associated Dermatitis in Hospitalized Elderly Patients: nurses' self-reported knowledge. Rev Pesqui: Cuid Fundam. 2018;10(3):801-9. doi: 10.9789/2175-5361.2018.v10i3.801-809

11. Beele H, Smet S, Damme NV, Beeckman D. Incontinence-Associated Dermatitis: pathogenesis, contributing factors, prevention and management options. Drugs Aging. 2017;35(1):1-10. doi: 10.1007/s40266-017-0507-1

12. Silva FF, Lindemann LG, Farias SR, Haertel JC, Santos LH, Rubira LT. Prevenção de dermatites associadas à incontinência em idosos no contexto domiciliar. Rev Gestão Saúde [Internet]. 2018 [cited 2018 Dec 5];18(2):1-9. Available from: http://www.herrero.com.br/files/revista/ file00a7cbe712997dc77ce935a5b6342300.pdf

13. Gray M, Giuliano K. K. Incontinence-Associated Dermatitis and Immobility as Pressure Injury Risk Factors. J Wound Ostomy Continence Nurs. 2018;34(1):45-54. doi:10.1097/won.0000000000000390

14. Chianca TCM, Gonçales PC, Salgado PO, Machado BO, Amorim GL, Alcoforado CLGC. Incontinence-associated dermatitis: a cohort study in critically ill patients. Rev Gaúcha Enferm. 2016;37:1-8. doi: 10.1590/1983-1447.2016.esp.68075

15. Kayser SA, Phipps L, VanGilder CA, Lachenbruch C. Examining Prevalence and Risk Factors of Incontinence-Associated Dermatitis Using the International Pressure Ulcer Prevalence Survey. J Wound Ostomy Continence Nurs. 2019;46(4):285-90. doi: 10.1097/ WON.0000000000000548

16. Beeckman D, Verhaeghe S, Defloor T, Schoonhoven L, Vanderwee K. A 3-in-1 perineal care washcloth impregnated with dimethicone 3\% versus water and $\mathrm{pH}$ neutral soap to prevent and treat incontinence associated dermatitis: a randomized, controlled clinical trial. J Wound Ostomy Continence Nurs. 2011;38(6):627-34. doi:10.1097/won.0b013e31822efe52

17. Bertolucci PHF, Brucki SMD, Campacci SR, Juliano Y. O Mini-Exame do Estado Mental em uma população geral; impacto da escolaridade. Arqu Neuro-Psiquiatr[Internet]. 1994 [cited 2018 Nov 30];52(1):1-7. Available from: http://www.scielo.br/pdf/rgenf/v37nspe/ en_0102-6933-rgenf-1983-14472016esp68075.pdf

18. Folstein MF, Folstein SE, Mchugh PR. Mini-mental state: A practical method for grading the cognitive state of patients for the clinician. J Psychiatr Res. 1975;12(3):189-98. doi: 10.1016/0022-3956(75)90026-6

19. Beeckman D, Campbell JL, Campbell K, Chimentão D, Domansky R, Gray M, et al. Incontinence-associated dermatitis: moving prevention forward. Wounds Int [Internet]. 2015 [cited 2018 Out 01];1-24. Available from: https://www.woundsinternational.com/resources/details/ incontinence-associated-dermatitis-moving-prevention-forward.

20. Campbell JL, Coyer FM, Osborne SR. Incontinence-associated dermatitis: a cross-sectional prevalence study in the Australian acute care hospital setting. Int Wound J. 2014;13(3):403-11. doi: 10.1111/iwj.12322

21. Wei L, Bao Y, Chai Q, Zheng J, Xu W. Determining risk factors to develop a predictive model of Incontinenceassociated Dermatitis among critically ill patients with fecal incontinence: a prospective, quantitative study. Wound Manag Prevent [Internet]. 2019 [cited 2019 Oct 20];65(4):24-33. Available from: https://www.o-wm.com/article/ determining-risk-factors-develop-predictive-model-incontinence-associated-dermatitis-among

22. Barcelos RA, Tavares DMS. Factors associated with patient safety incidents among elderly people in intensive care. Acta Paul Enferm. 2017;30(2):159-67. doi: 10.1590/1982-0194201700025

23. Arco HMSLR, Costa A, Gomes B, Anacleto N, Silva R, Fonseca S. Intervenções de enfermagem na dermatite associada à incontinência: revisão integrativa da literatura. Enferm Glob[Internet]. 2018 [cited 2019 Oct 28];17(4):703-16. doi: 10.6018/eglobal.17.4.319491

24. Valls-Matarín J, Del Cotillo-Fuente M, Ribal-Prior R, Pujol-Vila M, Sandalinas-Mulero I. Incidencia de lesiones cutáneas asociadas a la humedad en una unidad de cuidados intensivos. Enferm Intens. 2017;28(1):13-20. doi: 10.1016/j.enfi.2016.11.001

25. Ma ZZ, Song JY, Wang M. Investigation and analysis on occurrence of incontinence-associated dermatitis of ICU patients with fecal incontinence. Int J Clin Experimental Med [Internet]. 2017 [cited 2019 Oct 20];10(5):7443-9. Available from: http://www.ijcem.com/files/ ijcem0016986.pdf

26. Ousey K, O'Connor L. Incontinence-associated dermatitis Made Easy. Wounds UK [Internet]. 2017 [cited 2019 Dec 01];13(1):1-6. Available from: http://eprints.hud.ac.uk/id/eprint/31572/1/content_11936.pdf

27. Diz JBM, Queiroz BZ, Tavares LB, Pereira LSM. Prevalence of sarcopenia among the elderly: findings from broad cross-sectional studies in a range of countries. Rev Bras Geriatr Gerontol. 2015;18(3):665-78. doi: 10.1590/1809-9823.2015.14139

28. Chagas NMS, Borges DGS, Chagas MHN. Delirium como fator de risco para demência em idosos: uma atualização. J Bras Psiquiatr. 2016;65(1) 94-8. doi: 10.1590/0047-2085000000109 